\title{
THE EFFECT OF INDUSTRIAL WORK PRACTICE, GUIDANCE INTENSITY OF INDUSTRIAL SIDE, AND VOCATIONAL COMPETENCE ON WORKING READINESS OF GRADE XII STUDENTS OF BANKING PROGRAM, VOCATIONAL HIGH SCHOOL PERBANKAN, PEKANBARU
}

\author{
Dwi Yana Putri \\ Technology and Vocational Education-Postgraduate Program, Universitas Negeri Yogyakarta \\ dwiyanaputri15@gmail.com \\ Sutarto \\ Education of Civil Engineering \& Planning-Faculty of Engineering, Universitas Negeri Yogyakarta \\ sutarto@uny.ac.id
}

\section{Abstract}

This study aimed to find out the effect of: (1) industrial work practice, (2)guidance intensity of industrial side, (3)vocational competence, and (4) industrial work practice,guidance intensity of industrial side, and vocational competence on the working readiness of students of Vocational High School (VHS) PerBankan Pekanbaru. This research was ex-post facto research. The population was all students of class XII Program of Banking in the academic year of 2017/2018 which comprised 106 students who followed industrial work practice. A sample of 83 students was processed using the Proportional Random sampling technique. Prior to doing research, the instrument first validated the expert. After validated experts tested the validity and reliability to determine the valid and reliable instrument items. Data analyst technique used is descriptive research method, prerequisite test, and regression analysis. The results showed that: (1) industrial work practice $\left(x_{1}\right)$ has a positive and significant effect on students'working experience (y) evidenced by $t_{\text {hitung }} \geq t_{\text {tabel }}(2,414>1,98)$ contribution of $27,63 \%$; (2) the guidance intensity of industrial side $\left(x_{2}\right)$ had a positive and significant effect on students'working readiness (y) evidenced by $t_{\text {hitung }} \geq t_{\text {tabel }}(2,822>1,98)$ contribution of $21,03 \%$; (3) vocational competence $\left(x_{3}\right)$ had a positive and significant effect on students'working readiness (y) evidenced by $t_{\text {hitung }} \geq t_{\text {tabel }}(2,348>1,98)$ contribution of $2,46 \%$; (4) industrial work practice, guidance intensity of industrial side, and vocational competence simultaneously had a positive effect on students'working readiness (y) evidenced by $F_{\text {hitung }} \geq F_{\text {tabel }}(16,235>3,11)$ with contribution of $51,12 \%$. The rest $48,88 \%$ was determined by other factors.

Keywords: industrial work practice, guidance intensity of industrial side, vocational competence, students working readiness 


\section{INTRODUCTION}

Education is one of the important aspects of the progress of the State. Advanced education will produce intelligent and skilled people. The statement is in line with the definition of education in Law No. 20 of 2003 on National Education System (Department of National Education, 2003):

\section{"Education is a planned conscious effort to create an atmosphere of teaching and learning process so that learners actively develop their potential to have spiritual power, self-control, personality, intelli- gence, noble character, and skills needed by students, society, nation and state."}

Nowadays, educational programs are directed to develop skills for learners. Schools, teachers and other stakeholders are expected to provide facilities to support students' skills. Vocational High School is a School that is designed to develop the skills of students as one of the institutions that are obliged by the government to prepare its graduates to work in some industrials. As stated in the explanation of Law Number 20 of 2003 on the National Education System (UUSPN No. 20 of 2003) that vocational education is an education that prepares students to be able to work in a particular field. Thus, vocational education serves as a means of preparation to work in some industrials. The implementation of education in vocational School is always adjusted to the conditions and needs of industrial. But data obtained from the Central Bureau of Statistics (CBS) released the number of unemployed in Indonesia of a August 2017 reached 7.04 million people. This number increased 10 thousand people compared to August 2016. Meanwhile, the Open Unemployment Rate (OUR) reached $5.50 \%$. Of the $5.50 \%$ OUR, the highest unemployment is a graduate of Vocational High School with a percentage of $11.41 \%$.In brief, the percentage increased compared to August 2016 which only reached $11.11 \%$ (Murdaningsing, 2017).

According to Nore \& Lahn (2014) in the debates about vocational education and training (VET), the interaction between School and work is a recurrent theme. The purpose of Vocational High School is to prepare graduates ready to enter the world of work or industrial. One of the most accepted departments of the labor market is banking. The banking is one of the most wanted job by job seekers in Indonesia. People with a variety of educational backgrounds also apply for jobs in the Bank.

Working readiness is an ability that indicates coordination between the factors that influence it must be owned by someone to achieve the goal to be able to work immediately after graduation without requiring a period of adjustment takes a long time. Student readiness is influenced by internal factors that come from the students themselves include maturity both physical and mental, pressure, creativity, interest, talent, intelligence, independence, mastery of science, and motivation. Other factors are external factors that come from outside the students themselves include the role of society, families, facilities and infrastructure Schools, information about industrials, and work experience. Students are said to be ready to work, if they have optimal maturity and intelligence. But in real circumstances, not all vocational students have optimal maturity and intelligence that can support them in preparing themselves to work in famous industrials. Therefore, Vocational High School held a learning program that can support graduates who are ready to work in some industrials is called called internships. The internship program aims to enable students to directly apply their skills in industrials (Tamrin, Slamet, \& Soenarto, 2018). The apprentice system in Germany is called Dual System or Multiple System Education because it combines job training with theories taught in School one or two days per week (Petrosky, 2). Deissinger (2010) suggested Dual System can be applied by giving training and vocational education in full time in partner institutions. The main purpose of dual system is to produce skilled workers, qualified, have flexible working ability according to their field.

One of the efforts to improve the quality and relevance of vocational education is the enhancement of link and match. Dual system education which is based on link and match policy expect vocational education competence will be implemented in two places. Some educational competencies are carried out in the School, namely vocational theories and basic practices, and some are implement- 
ed in the workplace such as productive skills gained through learning by doing (Mardiyah \& Supriyadi, 2013). According to Supriadi (2002), link and match can provide implications for human resource, future, quality and excellence, professionalism, value-added and economic insight in the organization of vocational education. Based on the above description, it can be stated that the implementation of Dual System Education emphasizes the integration of education in Schools with education obtained in the company. Dual System Education provides an efficient way of producing high graduates in technology (Göhringer, 2002).

Industrial work practice is an activity between Vocational High School and industry as part of Dual System Education. It is a productive skills activity carried out by the vocational School students in the business world / industrial world that has the aim of improving the ability of the learners (Prasetyo, 2013). Dikmenjur (2008) suggested that it is a concrete manifestation of Dual System Education in which the learning program implemented by learners is done in the world of work. In brief it is a productive skills program implemented by Vocational School students in some industrials as part of Dual System Program.

The students shoud get any guidances industrial work practice. The word "intensity" comes from English (Echols \& Shadily, 2014, p. 326). In the Great Indonesian Dictionary of the Ministry of National Education (Departemen Pendidikan Nasional, 2008, p. 506) intensity is defined as "its state, level, and intense measure". Intensity is the unanimity of effort mobilized for a business. So the intensity is the amount of effort and sincerity done by someone in doing certain activities. Meanwhile, the word guidance is derived from the verb "to guide" (Hallen, 2002, p. 3). In short the intensity of guidance can be interpreted the number of efforts and seriousness done by a person in performing a psychological process of assistance in the form of knowledge, understanding and certain competencies to help individuals or groups in order to develop the capabilities students have. Consequently,the students should be able to develop their ability such as money calculations, registration, operation of the work equipment (computer, scanning equipment, etc.), opening new customer accounts, documentation and other works related to all Bank activities and other financial services.

One of educational backgrounds is the competence or expertise possessed, both from School education and industrial work practice. Spencer stated that competence is as a basic characteristic possessed by an individual who deals causally in meeting the criteria required to occupy a position (Palan, 2007). Competence consists of 5 (five) types of characteristics: motives (consistent willingness as well as the cause of action), innate factors (character and consistent response), self concept (self-image), knowledge (information in a particular field) and skills to perform the task). Government Regulation (PP) Law No. 23 of 2004 (Presiden Republik Indonesia, 2004) on the National Agency for Professional Certification (BNSP) describes the certification of work competence as a process of awarding competency certificates that are conducted systematically and objectively through competency tests referring to the national and international work competency standards. Pavlova (2010, p. 9) states about the competencies defined as follows:

"The definition of competence adopted by the committee recognized that performance is underpinned not only by skill, but also by knowledge and understanding, and they involve both the ability to perform in a given context and the capacity to transfer knowledge and skills to new tasks and situations."

From the definition above, it can be interpreted that vocational competence in the wider scope is not only limited to the ability but also related to the profile of the attitude, mental and understanding of a person in carrying out his work or in other words the value of competency in hard skill and soft skills. Vocational competence also relates to the contribution that an individual professional can make to a better economic change.

Based on Decree of Director General of Primary and Secondary Education Number: 330/D.D5/KEP/KR/2017 the banking program has Core Competence and Basic Competence as follows: (1) Communication competence (2) money calculation competence (3) competence in doing transaction in the bank (4) competence of office equipment use (5) cor- 
respondence competence (6) administrative competence and accounting (7) competence in managing service and trade accounting cycles (8) competence to manage the Cash of Banks and Small Cash (9) competence to operate the processing of numbers (10) documentation competence.

Referring to the above descriptions, the purpose of this study is to determine the level of each variable and to know the influence (1) industrial work practice; (2) guidance intensity of industrial side; (3) vocational competence; (4) guidance intensity of industrial side, and students' vocational competencies stimultanouly on the working readiness of the students of banking of Vocational High School Perbankan Pekanbaru.

\section{RESEARCH METHOD}

This research is an ex-post facto research. It research is a study in which independent variables have occurred when the researcher began with observation of dependent variables in a study. Ex-post facto research was chosen to find the effect of independent variables on dependent variable. This research was conducted to find the influence of industrial work practice, guidance intensity of industrial side, and vocational competence on the readiness of students' work. This research includes descriptive research with quantitative approach.

This research was conducted in Vocational High School Perbankan in Pekanbaru: Vocationah High Schol of Perbankan Riau which is located on Jl. Majalengka, Sidomulyo Tim., Marpoyan Damai, Kota Pekanbaru, Riau and Vocational High School of IT AlIzhar School Perbankan Syariah which is located on Jl.HR.Soebrantas Km.15. It was carried out from January 2018 involving observation, instrument making, data collection and research report.

The population of this research was taken from all of twelveth graders of Banking Program of Banking Vocational High Schools Pekanbaru academic year 2017/2018. The total of population was 106 which wastaken from 73 students of Vocationah High School Perbankan Riau and 33 students of Vocational High School of IT Al-Izhar School Perbankan Syariah. They were chosen as population of this research because they had industrial work practice experience. Besides, they had prior knowledge about banking.

The sample was taken using (Isaac \& Michael (1983, p. 192) formula:

$$
s=\frac{X^{2} N P(1-P)}{d^{2}(N-1)+X^{2} \cdot P(1-P)}
$$

The sample technique used in this research is Propotional Random Sampling. The sample is taken proportionally based on number of students of each School using the following formula:

$$
s=\frac{n}{N} \times S
$$

In this research, documentation and closed questionnaire method was used. Documenation was used to measure independent variables: Vocational Competence, in which the data were taken from semester one report result of grade twelve of 2017//2018 and students' practical industrial work' scores of Banking Program in Pekanbaru Academic Year 2016/2017.

Questionnaire was used to obtain data about the experience of industrial work practice, guidance intensity of industrial side and the readiness of the students of class XII of Vocatioan High School Perbankan in the academic year 2017/2018. A written questionnaire was given to the respondentsusing Likert scale with four alternative answers are as follows: strongly agree, agree, disagree, and strongly disagree.

The technique used was descriptive analysis, test of precondition analysis, multiple regression hypotheses. In the descriptive analysis, table, chart, diagram, mean, modus, median, and standard deviation are presented. Before data analysis was done, precondition analysis test was conducted: (1) normality test, (2) linearity test, and (3) multicolinearity test.

Multiple regression analysis is used to determine the state of the dependent variable if the predictor value of the independent variable is manipulated. The magnitude of the influence of industrial work practice (X1), the magnitude of intencity guidance of industrial side (X2), and the variability of vocational competencies (X3) that can be varied which is used to predict students' work readiness $(\mathrm{Y})$. The equations used is:

$$
Y=a+b 1 X_{1}+b 2 X_{2}+b 3 X_{3}
$$




\section{RESEARCH FINDINGS AND DISCUSSION}

\section{Research Findings}

Precondition analysis test consits of normality test, linearity test, and multicoliniearity test.

\section{Normality Test}

Normality test was conducted using SPSS 20 for windows. The results of the test are presented in table 1 . Normality test using KolmogorovSmirnov is normally distributed if Asymp. Sig ( 2 tailed) value > 0,05 at level significant $(\alpha)$.

Table 1. The results of Normality Test

\begin{tabular}{|c|c|c|c|}
\hline Variable & $\begin{array}{l}\text { Asymp. } \\
\text { Sig. }\end{array}$ & Criterion & Result \\
\hline $\begin{array}{l}\text { Industrial Work } \\
\text { Practice }\end{array}$ & 0,350 & \multirow{4}{*}{$>0,05$} & $\begin{array}{l}\text { Normally } \\
\text { Distributed }\end{array}$ \\
\hline $\begin{array}{l}\text { Guidance Intensity } \\
\text { of Industrial Side }\end{array}$ & 0,980 & & $\begin{array}{l}\text { Normally } \\
\text { Distributed }\end{array}$ \\
\hline $\begin{array}{l}\text { Vocatioanal } \\
\text { Competence }\end{array}$ & 0,110 & & $\begin{array}{l}\text { Normally } \\
\text { Distributed }\end{array}$ \\
\hline $\begin{array}{l}\text { Students' Working } \\
\text { Readiness }\end{array}$ & 0,518 & & $\begin{array}{l}\text { Normally } \\
\text { Distributed }\end{array}$ \\
\hline
\end{tabular}

Normality test using KolmogorovSmirnov indicates that Asymp. Sig (2 tailed) value for Industrial Work Practice is $0,350>$ 0,05 at level significant $(\alpha)$, Asymp. Sig (2 tailed) value for Guidance Intensity of Industrial Side is $0,0980>0,05$ at level significant $(\alpha)$, Asymp. Sig (2 tailed) value for Vocational Competence is $0,110>0,05$ at level significant $(\alpha)$, and Asymp. Sig ( 2 tailed) value for Students' Working Readiness is 0,518>0,05 at level significant $(\alpha)$. In brief, all the variable data are normally distributed.

\section{Linearity Test} windows.

Linearity was done using SPSS 20.0 for

Table 2. The Results of Linearity Test

\begin{tabular}{llll}
\hline Variable & Sig. & Criterion & Result \\
\hline $\begin{array}{l}\text { Industrial Work } \\
\text { Practice }\end{array}$ & 0,689 & & Linier \\
$\begin{array}{l}\text { Guidance Intensity of } \\
\text { Industrial Side }\end{array}$ & 0,476 & $>0,05$ & Linier \\
$\begin{array}{l}\text { Vocatioanal } \\
\text { Competence }\end{array}$ & 0,152 & & Linier \\
\hline
\end{tabular}

Based on Table 2, it is clearly displayed that significance value on deviation from liniearity of the Industrial Work Practice $\left(\mathrm{X}_{1}\right)$ and Students' Working Readiness Variable (Y) is $0,689>0,05$. It indicates that the relationship between the two variables are linear. The significance value on deviation from liniearity of the Guidance Intesity of Industrial Side $\left(\mathrm{X}_{2}\right)$ and Students' Working Readiness Variable (y) is $0,475>0,05$. It indicates that the relationship between the two variables are linear. The significance value on deviation from liniearity of the Vocational Competence $\left(\mathrm{X}_{3}\right)$ and Students' Working Readiness Variable (y) is $0,152>0,05$. It indicates that the relationship between the two variables are linear.

\section{Multicolinearity Test}

The results of linearity test was performed using SPSS 20,0 for Windows which are presented in table 3. The multicolinearity test was conducted using Variance Inflation Factor (VIF) technique .

Table 3. The Results of Multicolinearity Test

\begin{tabular}{|c|c|c|c|c|c|}
\hline Variable & $\begin{array}{l}\text { Tole- } \\
\text { rance }\end{array}$ & $\begin{array}{l}\text { Crite- } \\
\text { reon }\end{array}$ & VIF & $\begin{array}{l}\text { Crite- } \\
\text { reon }\end{array}$ & Result \\
\hline $\begin{array}{l}\text { Industrial } \\
\text { Work } \\
\text { Practice }\end{array}$ & 0,567 & & 1,764 & & $\begin{array}{l}\text { Multico- } \\
\text { linearity } \\
\text { doesn't } \\
\text { occur }\end{array}$ \\
\hline $\begin{array}{l}\text { Guidance } \\
\text { Intensity of } \\
\text { Industrial } \\
\text { Side }\end{array}$ & 0,572 & $>0,1$ & 1,750 & $<10$ & $\begin{array}{l}\text { Multico- } \\
\text { linearity } \\
\text { doesn't } \\
\text { occur }\end{array}$ \\
\hline $\begin{array}{l}\text { Vocatioanal } \\
\text { Competence }\end{array}$ & 0,985 & & 1,015 & & $\begin{array}{l}\text { Multico- } \\
\text { linearity } \\
\text { doesn't } \\
\text { occur }\end{array}$ \\
\hline
\end{tabular}

Multicolinearity doesn't occur if coefisien ( $r$ ) inter dependent variable is lower or equal 0,60 ( $\mathrm{r} \leq 0,60)$. On the other sides, multicolinearity occurs if $\alpha$ counted $>\alpha$ and VIF counted < VIF. Tolerance $(\alpha)$ of this test is $10 \%$, so that $\alpha$ counted must be higher than $10 \%(0,1)$ and VIF counted must be lower than 10 .

The results of the multicolinearity test using SPSS 20.0 for Windows explains that: the tolerance value of the Industrial Work Practice $(\mathrm{X} 1)$ is $0,567>0,1$ and VIF value is $1,764<10$. Thus, multicolinearity doesn' occur. the tolerance value of Guidance Inten- 
sity of Industrial Side (X2) is $0,572>0,1$ and VIF value is $1,750<10$. It indicates that multicolinearity doesn' occur. the tolerance value of Vocational Competence (X3) is $0,985>0,1$ and VIF value is $1,015<10$. It indicates that multicolinearity doesn' occur.

\section{Hypothesis Test}

\section{First Hypothesis Test}

The first hypothesis of this research is the effect of industrial work practice on students' working readiness.This hypothesis was done by looking at the value of $t_{\text {obtained }}$ and $t_{\text {table }}$ for 83 samples with sig $<5 \%(0,05)$. If $t_{\text {obained }}$ is higher than $t_{\text {table }}$, Ho is rejected and Ha is accepted.

Table 4. The Results of Multiple Regression for the First Hypothesis

\begin{tabular}{cccccc}
\hline $\begin{array}{c}\text { Unstandardized } \\
\text { Coefficients }\end{array}$ & $\begin{array}{c}\text { Standardized } \\
\text { Coefficients }\end{array}$ & \multirow{2}{c}{$\mathrm{t}$} & Sig. \\
\cline { 1 - 3 } B & Std. Error & Beta & & \\
\hline .291 & .121 & .284 & 2.414 & .018 \\
\hline
\end{tabular}

Table 4 demonstrates that the value of $t_{\text {obained }}>t_{\text {table }}(2,414>1,98)$ at significance level $5 \%$ with $\mathrm{p}$ value is 0,05 . It shows that $\mathrm{Ha}$ is accepted and $\mathrm{Ho}$ is rejected. In short, industrial work practice had a significant effect on the working readiness of twelveth grade students' of banking program of Vocational High School Perbankan Pekanbaru academich year 2017/2018.

\section{Second Hypothesis Test}

The second hypothesis of this research is the effect of guidance intensity of industrial side on students' working readiness.This hypothesis was done by looking at the value of $\mathrm{t}_{\text {obtained }}$ and $\mathrm{t}_{\text {table }}$ for 83 samples with sig < $5 \%(0,05)$. If $t_{\text {obained }}$ is higher than $t_{\text {table }}$, Ho is rejected and $\mathrm{Ha}$ is accepted.

Table 5. The Results of Multiple Regression for the Second Hypothesis

\begin{tabular}{cccccc}
\hline $\begin{array}{c}\text { Unstandardized } \\
\text { Coefficients }\end{array}$ & \multicolumn{2}{c}{$\begin{array}{c}\text { Standardized } \\
\text { Coefficients }\end{array}$} & \multirow{2}{c}{ t } & Sig. \\
\cline { 1 - 3 } B & Std. Error & Beta & & \\
\hline .209 & .074 & .330 & 2.822 & .006 \\
\hline
\end{tabular}

Table 5 displays that the value of $\mathrm{t}_{\text {obained }}$ $>t_{\text {table }}(2,822>1,98)$ at significance level $5 \%$ with $\mathrm{p}$ value is 0,05 . It shows that $\mathrm{Ha}$ is accepted and Ho is rejected. In brief, the guidance intensity of industrial side had a significant effect on the working readiness of twelveth grade students' of banking program of Vocational High School Perbankan Pekanbaru academich year 2017/2018.

\section{Third Hypothesis Test}

The third hypothesis of this research is the effect of vocational competence on students' working readiness. This hypothesis was done by looking at the value of $\mathrm{t}_{\text {obtained }}$ and $\mathrm{t}_{\text {table }}$ for 83 samples with sig < 5\% $(0,05)$. If $t_{\text {obained }}$ is higher than $t_{\text {table, }}$, Ho is rejected and Ha is accepted.

Table 6. The Results of Multiple Regression for Third Hypothesis

\begin{tabular}{ccccc}
\hline $\begin{array}{c}\text { Unstandardized } \\
\text { Coefficients }\end{array}$ & \multicolumn{2}{c}{$\begin{array}{c}\text { Standardized } \\
\text { Coefficients }\end{array}$} & & \multirow{2}{*}{ Sig. } \\
\cline { 1 - 4 } B & Std. Error & Beta & & \\
\hline .346 & .147 & .209 & 2.348 & .021 \\
\hline
\end{tabular}

Table 6 clearly shows that the value of $t_{\text {obained }}>t_{\text {table }}(2,348>1,98)$ at significance level $5 \%$ with $\mathrm{p}$ value is 0,05 . It means that $\mathrm{Ha}$ is accepted and Ho is rejected. In brief, the vocational competence had a significant effect on the working readiness of twelveth grade students' of banking program of Vocational High School Perbankan Pekanbaru academich year 2017/2018.

\section{Forth Hypothesis Test}

The forth hypothesis of this research is the effect of industrial work practice, guidance intensity of industrial side, and vocational competence on students' working readiness. This hypothesis was tested uisng multiple regression analysis and further processed using SPSS 20.0 for Windows. If $t_{\text {obtained }}$ is higher than $t_{\text {table }}$ for 83 samples at significant level 5\% $(0,05)$, Ho is rejected and Ha is accepted.

Table 7. The Results of Multiple Regression for Forth Hypothesis

\begin{tabular}{clccc}
\hline $\begin{array}{c}\mathrm{r} \\
\text { (correlation) }\end{array}$ & $\begin{array}{c}\mathrm{r}^{2} \\
\text { (determination) }\end{array}$ & $\mathrm{F}$ & Sig & Conclusion \\
\hline 0,618 & 0,381 & 16,235 & $.015^{\mathrm{b}}$ & Significant \\
\hline
\end{tabular}


The analysis results using SPSS 20,0 for Windows show that $\mathrm{F}_{\text {obtained }}>\mathrm{F}_{\text {table }}(16,235>$ $3,11)$ and $\alpha_{\text {obtained }}<\alpha_{i}(0,015<0,05)$. It means $\mathrm{Ha}$ is accepted and $\mathrm{Ho}$ is rejected. In conclusion, industrial work practice, guidance intensity of industrial side, and vocational competence simultanously had a significant effect on the working readiness of twelveth grade students' of banking program of Vocational High School Perbankan Pekanbaru academich year 2017/2018

\section{Relative and Effective Contribution}

Relative and effective contribution aims to find out contribution of every predictor variable on criterium. The calculation using SPSS 20,0 for Windows shows that industrial work practice $\left(X_{1}\right)$ has coefisien value 0,291 , guidance intensity of industrial side $\left(\mathrm{X}_{2}\right)$ has coefisien value 0,209 , and vocational competence $\left(\mathrm{X}_{3}\right)$ has coefisien value 0,346 . Therefore, the regression equation is as follows:

$$
Y=62,637+0,291 X 1+0,209 X 2+0,346 X 3
$$

Note:

$\mathrm{X}_{1}=$ Industrial Work Practice

$\mathrm{X}_{2}=$ Guidance Intensity of Industrial Side

$\mathrm{X}_{3}=$ Vocational Competence

$\mathrm{Y}=$ Students' Working Readiness

The constant value of this equation is 62,637 . Thus, If industrial work practice $\left(X_{1}\right)$, guidance intensity of industrial side $\left(\mathrm{X}_{2}\right)$, and vocational competence $\left(\mathrm{X}_{3}\right)$ is assumed 0 , it means the students' working readiness $(\mathrm{Y})$ is 62,637 points. The coefisien regression value of industrial work practice $\left(X_{1}\right)$ is 0,291 . The students' working readines $(\mathrm{Y})$ will increase 0,291 point if industrial work practice variable $\left(\mathrm{X}_{1}\right)$ increases 1 point with an assumption that guidance intensity of industrial side variable $\left(\mathrm{X}_{2}\right)$, and vocational competence variable $\left(\mathrm{X}_{3}\right)$ are fixed. The coefisien regression value of guidance intensity of industrial side $\left(\mathrm{X}_{2}\right)$ is 0,209 . The students' working readines $(\mathrm{Y})$ will increase 0,209 point if guidance intensity of industrial side variable $\left(\mathrm{X}_{2}\right)$ increases 1 point with an assumption that industrial work practice variable variable $\left(\mathrm{X}_{1}\right)$, and vocational competence variable $\left(\mathrm{X}_{3}\right)$ are fixed. The coefisien regression value of vocational competence variable $\left(\mathrm{X}_{3}\right)$ is 0,346 . The students' working readines $(\mathrm{Y})$ will increase 0,346 point if vocational competence variable $\left(\mathrm{X}_{3}\right)$ increases 1 point with an assumption that industrial work practice variable variable $\left(\mathrm{X}_{1}\right)$, guidance intensity of industrial side variable $\left(\mathrm{X}_{2}\right)$ are fixed.

The relative contribution of industrial work practice $\left(\mathrm{X}_{1}\right)$ on students' working readiness $(\mathrm{Y})$, guidance intensity of industrial $\operatorname{side}\left(\mathrm{X}_{2}\right)$ on students' working readiness $(\mathrm{Y})$, and vocational competence $\left(\mathrm{X}_{3}\right)$ on students' working readiness $(\mathrm{Y})$ are displayed in the following table.

Table 8. Coefisien Value b, Cross Product of Each Variable

\begin{tabular}{lcl}
\hline Variabel & B & \multicolumn{1}{c}{$\sum x y$} \\
\hline Praktik Kerja Industri & 0,291 & 1794,169 \\
Intensitas Bimbingan Pihak Industri & 0,209 & 1900,952 \\
Kompetensi Kejuruan & 0,346 & 134,181 \\
\hline
\end{tabular}

Based on Table 8 , relative distribution of each variable can be calculated using the following formula.

$$
\begin{aligned}
J K_{\text {reg }}= & a_{1} \sum x_{1} y+a_{2} \sum x_{2} y+a_{3} \sum x_{3} y \\
= & (0,291 \times 1794,169)+(0,209 \times 1900,952) \\
& +(0,346 \times 134,181) \\
= & 522,1+397,3+46,4 \\
= & 965,8 \\
S R x_{1} \%= & \frac{a_{1} \sum x_{1} y}{J K_{\text {reg }}} \times 100 \% \\
= & \frac{522,1}{965,8} x 100 \% \\
= & 57,39 \% \\
S R x_{2} \% & =\frac{a_{2} \sum x_{2} y}{J K_{\text {reg }}} \times 100 \% \\
= & \frac{397,3}{965,8} \times 100 \% \\
= & 41,13 \% \\
S R x_{3} \% & =\frac{a_{3} \sum x_{3} y}{J K_{\text {reg }}} \times 100 \% \\
= & \frac{46,4}{965,8} x 100 \% \\
= & 1,48 \% \\
\text { SR } x_{1} \% & +S R x_{2} \%+S R x_{3} \%=57,39 \%+41,13 \% \\
+1,48 \%= & 100 \%
\end{aligned}
$$

Furthermore, the effective contribution of the independent variable of industrial work practice $\left(\mathrm{X}_{1}\right)$ to the dependent variable of students' working readiness (Y), effective contribution of independent variable of guidance intensity of industrial side $\left(\mathrm{X}_{2}\right)$ to the dependent variable of students' working 
readiness $(\mathrm{Y})$ and effective contribution of vocational competence independent variable $\left(X_{3}\right)$ to the dependent variable of students' work readiness $(\mathrm{Y})$ are calculated using the following formula.

$$
\begin{aligned}
\text { SE } X_{1} \% & =\left(a X_{1} \cdot \sum x_{1} y \cdot R^{2} \cdot 100 \%\right) \\
& =(0,291 \cdot 1794,169 \cdot 0,381 \cdot 100 \%) \\
& =27,63 \% \\
\text { SE } X_{2} \% & =\left(a X_{2} \cdot \sum x_{2} y \cdot R^{2} \cdot 100 \%\right) \\
& =(0,209 \cdot 1900,952 \cdot 0,381 \cdot 100 \%) \\
& =21,03 \% \\
\text { SE } X_{3} \% & =\left(a X_{3} \cdot \sum x_{3} y \cdot R^{2} \cdot 100 \%\right) \\
& =(0,346 \cdot 134,181 \cdot 0,381 \cdot 100 \%) \\
& =2,46 \% \\
\text { SE Total } \% \quad & =S E X_{1} \%+S E X_{2} \%+S E X_{3} \% \\
& =27,63 \%+21,03 \%+2,46 \% \\
& =51,12 \%
\end{aligned}
$$

From the total of effective contribution $(51,12 \%)$ can be described that industrial work practice variable $\left(\mathrm{X}_{1}\right)$ has effective contribution $27,63 \%$, guidance intensity of industrial side varible $\left(\mathrm{X}_{2}\right)$ has effective contribution $21,03 \%$, and vocational competence variable $\left(\mathrm{X}_{3}\right)$ has effective contribution $2,46 \%$. The other unlimited variables in this research has effective contribution $48,88 \%$.

\section{Discussion}

This discussion is delivered based on the research findings which is reffered to the following formulation of problem:

\section{The Effect of Industrial Work Practice $\left(X_{I}\right)$ on Students' Working Readiness (Y).}

Students can get valuable knowledge and competence through industrial work practice. Competence persons are ones who have large knowledge and experiences related to their skills. Experiences, guidance, and competence can be obtained by actively taking part in the workplace. The experiences obtained in the workplace could give a significant effect on the students' work quality. The better work quality the better value can be obtained. At the same time, they also will be more ready to work.

The research findings indicate that there is a significant relationship among of the variables. It is found that $t_{\text {obtained }}$ is 5.554 which is bigger than $t_{\text {table }}(1.98)$ at significant level 5\%. As the result, Ho is rejected and $\mathrm{Ha}$ is accepted. On the other words, there is a significant relationship between industrial work practice on the working readiness of twelveth grade students' of banking program of Vocational High School Perbankan Pekanbaru academic year 2017/2018. It means that the students will have higher working readiness if they seriously take part in the work place. Therefore, to prepare the stu-dents' working readiness, good industrial work practice is definitely required.

The Effect of Guidance Intensity of Industrial Side $\left(\mathrm{X}_{2}\right)$ on Students' Working Readiness (Y)

Guidance intensity of industrial side means the amount of guidance given to students in developing their skills. The guidance given has large influence on the students' knowledge. The students' work quality is absolutely influenced by knowledge obtained in the industrial. Therefore, the more guidance students get, the more they can learn from it. On the other words, the students' working readiness is also influenced by guidance intensity.

The research findings indicate that there is a significant relationship among of the variables. It is found that $t_{\text {obtained }}$ is 5.663 which is bigger than $t_{\text {table }}(1.98)$ at significant level 5\%. As the result, $\mathrm{Ho}$ is rejected and $\mathrm{Ha}$ is accepted. On the other words, there is a significant relationship between guidance intensity of industrial side on the working readiness of twelveth grade students' of banking program of Vocational High School Perbankan Pekanbaru academic year 2017/2018.

This study also produces the same fact that the guidance given by the industry affects level of readiness of students' work. The data can be interpreted that the higher the intensity of the guidance of the industry, the higher the level of readiness of the students works. The low intensity of guidance given by in the industrial is caused by the unreadiness of the students. On the other words, they have lack of basic knowledge about industrial.

The Effect of Vocational Competence $\left(X_{3}\right)$ on Students' working Readiness (Y)

Vocational competence were measured based on both semester one report results of twelveth graders in academic year 2017/2018 and students' practical industrial work' scores 
of Banking Program in Pekanbaru Academic Year 2016/2017. The scores obtained can affect both the knowledge obtained either in theory or direct practice and improve the students' working readiness.

The research findings indicate that there is a significant relationship among of the variables. It is found that $t_{\text {obtained }}$ is 5.250 which is bigger than $t_{\text {table }}(1.98)$ at significant level 5\%. As the result, $\mathrm{Ho}$ is rejected and $\mathrm{Ha}$ is accepted. On the other words, there is a significant relationship between vocationl competence on the working readiness of twelveth grade students' of banking program of Vocational High School Perbankan Pekanbaru academic year 2017/2018.

Based on the data, the students' competence is categorized to good. On the other words, they are ready to compete in some industrials. As the result, Industrial can select qualified or competence students who are ready to work from Vocational High School graduates.

The Effect of Industrial Work Practice $\left(X_{1}\right)$, Guidance Intensity of Industrial Side $\left(X_{2}\right)$, and Vocational Competence $\left(X_{3}\right)$ on Students' Working Readiness (Y)

Based on the research findings, it is found that there is a significant relationship of industrial work practice, guidance intensity of industrial side, and vocational competence on the working readiness of twelveth grade students' of banking program of Vocational High School Perbankan Pekanbaru academic year 2017/2018. Based on F test, it is obtained that $\mathrm{F}_{\text {obtained }}>\mathrm{F}_{\text {table }}(16,235>3,11)$ and $\alpha_{\text {obtained }}$ $<\alpha_{\mathrm{i}}(0,015<0,05)$. It means $\mathrm{Ha}$ is accepted and $\mathrm{Ho}$ is rejected. In conclusion, industrial work practice, guidance intensity of industrial side, and vocational competence simultanously had a significant effect on the working readiness of twelveth grade students' of banking program of Vocational High School Perbankan Pekanbaru academich year 2017/2018

Industrial work practice, Guidance Intensity of Industrial Side, and Vocational Competence the working readiness of twelveth grade students' of banking program of Vocational High School Perbankan academic year 2017/2018 had correlation coefficient and determination $38.10 \%$. As the result, it is possible that the Practice of Industrial work practice, Guidance Intensity of Industrial Side, and Vocational Competence could be used as prediction of students' working readiness. This effect was also reinforced by effective contribution $51.12 \%$ that can be explained that the variable of Industrial work practice $\left(\mathrm{X}_{1}\right)$ had an effective contribution $27.63 \%$, Guidance Intensity of Industrial Side variable $\left(\mathrm{X}_{2}\right)$ had an effective contribution $21.03 \%$ and Vocational Competence $\left(\mathrm{X}_{3}\right)$ had an effective contribution $2.46 \%$.

It means that, the students' working readiness would also increase if the implementation of industrial work practice carried out well which is supported by the Guidance Intensity of Industrial Side and vocational competence obtained in the form of knowledge and practice increased, Consequently the purpose of vocational education that create graduates to be capable for work will be achieved. Therefore, after the students have done industrial work practice, the students will get direct experience visually about how the real world of work, improve their skills, and provide confidence for students in preparing themselves to join with work world after their graduation from vocational high School. Hopefully, the main purpose of Vocational High School to create capable students to work is reached.

\section{CONCLUSIONS}

Based on data analyses obtained, conclusions are drawn as follows:

First, the level of industrial work practice experience of the twelveth grade students' of banking program of Vocational High School Perbankan Pekanbaru was categorized to high with everage score 57,27 which can be seen in interval $61,95>\mathrm{X} \geq$ 57,28 . Second, the levelve of guidance intensity of industrial side given to the twelveth grade students' of banking program of Vocational High School Perbankan Pekanbaru was categorized to low with everage score 66,64 which can be seen in interval 66,64 > X $\geq 59,08$.

Third, the level of vocational competence obtained by the twelveth grade students' of banking program of Vocational High School Perbankan Pekanbaru was categorized to good/competence with everage score 89,17 which can be seen in interval 80-89. Fourth, The level of the working readiness of the 
twelveth grade students' of banking program of Vocational High School Perbankan Pekanbaru was categorized to low with everage score 62,39 which can be seen in interval $62,39>X \geq 57,60$.

Fifth, indusrial work practice had positive and significant effect on the working readiness of the twelveth grade students' of banking program of Vocational High School Perbankan Pekanbaru. It is concluded based on effective contribution value was $27,63 \%$ and $\mathrm{p}$ value was 0,00 . Sixth, guidance intensity of industrial side had positive and significant effect on the working readiness of the twelveth grade students' of banking program of Vocational High School Perbankan Pekanbaru. It is concluded based on effective contribution value was $21,03 \% \%$ and $p$ value was 0,00 .

Seventh, vocational competence had positive and significant effect on the working readiness of the twelveth grade students' of banking program of Vocational High School Perbankan Pekanbaru. It is concluded based on effective contribution value was $2,46 \%$ and $t_{\text {obtained }}$ value $>t_{\text {table }}(2,348>1,98)$ at significant level $5 \%$ and $\mathrm{p}$ value was 0,00 . Eighth, industrial work practice, guidance intensity of industrial side, vocationa competence simultanously had positive and significant effect on the working readiness of the twelveth grade students' of banking program of Vocational High School Perbankan Pekanbaru with contribution $51,12 \%$ and $\mathrm{R}^{2}=0,381$ and nilai $F_{\text {obtained }}>F_{\text {table }}(16,235>1,98)$ at significant level $5 \%$ and $\mathrm{p}$ value was 0.00 .

The suggestions that may be provided for this research are as follow:

First, to improve the quality of the implementation of industrial work practice the chief department of Banking expertise can convey to teachers competence in addition to science theory to master the techniques in the field of banking. The competency teacher of Banking is expected to perform guiding and supervision during the teaching practicum process. The contents of the general guidance of the material up to the practice of the students include the knowledge that students need in the industry and the necessary work practices after graduation to work in the workplace. In addition to the knowledge and practice teachers also provide materials related to the readiness of student work, among others: self-confidence, cooperation, quality of work, skills, initiative and creative and responsible.

Second, schools are expected to give clear guidance assessment to industrial in order that there is a common standard of assessment between industry. The Schools are expected to cooperate with some direct industrial which has been considered feasible for the implementation of industrial work practice so that it can be directly deployed to the workplace in accordance with the vocational program. The Schools are expected to better prepare students for taking part in the industrial so that it is easier to do guidance to students.

Third, industry is expected to provide good guidance to students who take part in the industrial work practice. By giving the list of tasks in the implementation of industrial work practice. Fouth, the School should improve the readiness of the students' work by providing training before conducting industrial work practice.

\section{REFERENCES}

Deissinger, T. (2010). Dual system. In P. Peterson, E. Baker, \& B. McGaw (Eds.), International Encyclopedia of Education Vol. 8 (pp. 448-454). Oxford: Elsevier.

Departemen Pendidikan Nasional. (2008). Kamus Besar Bahasa Indonesia (rev). Jakarta: Balai Pustaka.

Department of National Education. UndangUndang Nomor 20 Tahun 2003 tentang Sistem Pendidikan Nasional (2003).

Dikmenjur. (2008). Pelaksanaan prakerin. Jakarta: Departemen Pendidikan Nasional.

Echols, J. M., \& Shadily, H. (2014). Kamus Inggris Indonesia. Jakarta: Gramedia.

Göhringer, A. (2002, July 3). University of cooperative education - karlsruhe: the dual system of higher education in Germany. Retrieved from https://www.ijwil.org/files/APJCE_03_2 _53_58.pdf

Hallen, A. (2002). Bimbingan dan konseling dalam islami. Jakarta: Ciputat Pers.

Isaac, S., \& Michael, W. B. (1983). Handbook 
in research and evaluation: for education and the behavioral sciences (2nd ed.). California: EdITS Publishers.

Mardiyah, S. U. K., \& Supriyadi, E. (2013).

Evaluasi praktik kerja industri

kompetensi keahlian pemasaran SMKN

1 Pengasih, Kulon Progo. Jurnal

Pendidikan Vokasi2, 3(3), 320-333.

Retrieved from

https://journal.uny.ac.id/index.php/jpv/ar ticle/view/1846

Murdaningsing, D. (2017, November 6).

Pemerintah diminta perhatikan survei soal pengangguran. Republika. Retrieved from

https://www.republika.co.id/berita/dprri/berita-dpr-ri/17/11/06/oyzzq8368pemerintah-diminta-perhatikan-surveisoal-pengangguran

Nore, H., \& Lahn, L. C. (2014). Bridging the gap between work and education in vocational education and training. a study of norwegian apprenticeship training offices and E-portfolio systems. International Journal for Research in Vocational Education and Training, 1(1). Retrieved from http://www.ijrvet.net/index.php/IJRVET /article/view/16

Palan, R. (2007). Competency management, teknik mengimplementasikan manajemen SDM berbasis kompetensi untuk meningkatkan daya saing organisasi. Jakarta: PPM Anggota IKAP.
Pavlova, M. (2010). Technology and vocational education for sustainable development: empowering individuals for the future. (Vol. 10). Australia: Springer.

Prasetyo, B. (2013). Evaluasi pelaksanaan praktik kerja industri kompetensi keahlian teknik gambar bangunan SMK N 2 Klate. Skripsi. Fakultas Teknik Universitas Negeri Yogyakarta.

Presiden Republik Indonesia. Peraturan Pemerintah Republik Indonesia Nomor 23 Tahun 2004 tentang Badan Nasional Sertifikiasi Profesi (2004).

Supriadi, D. (2002). Sejarah pendidikan teknik dan kejuruan di Indonesia: Membangun manusia produktif. Jakarta: Departemen Pendidikan Nasional, Direktorat Jenderal Pendidikan Dasar dan Manengah, Direktorat Pendidikan Menengah Kejuruan.

Tamrin, A. G., Slamet, S., \& Soenarto, S. (2018). The link and match of the demand and supply for productive vocational school teachers with regard to spectrum of vocational skills in the perspective of education decentralization. Jurnal Pendidikan Vokasi, 8(1), 40. https://doi.org/10.21831/jpv.v8i1.15135 